$\infty$

\title{
WHAT YOU HEAR
} 5

\&WHAT WEEXPERIENCE

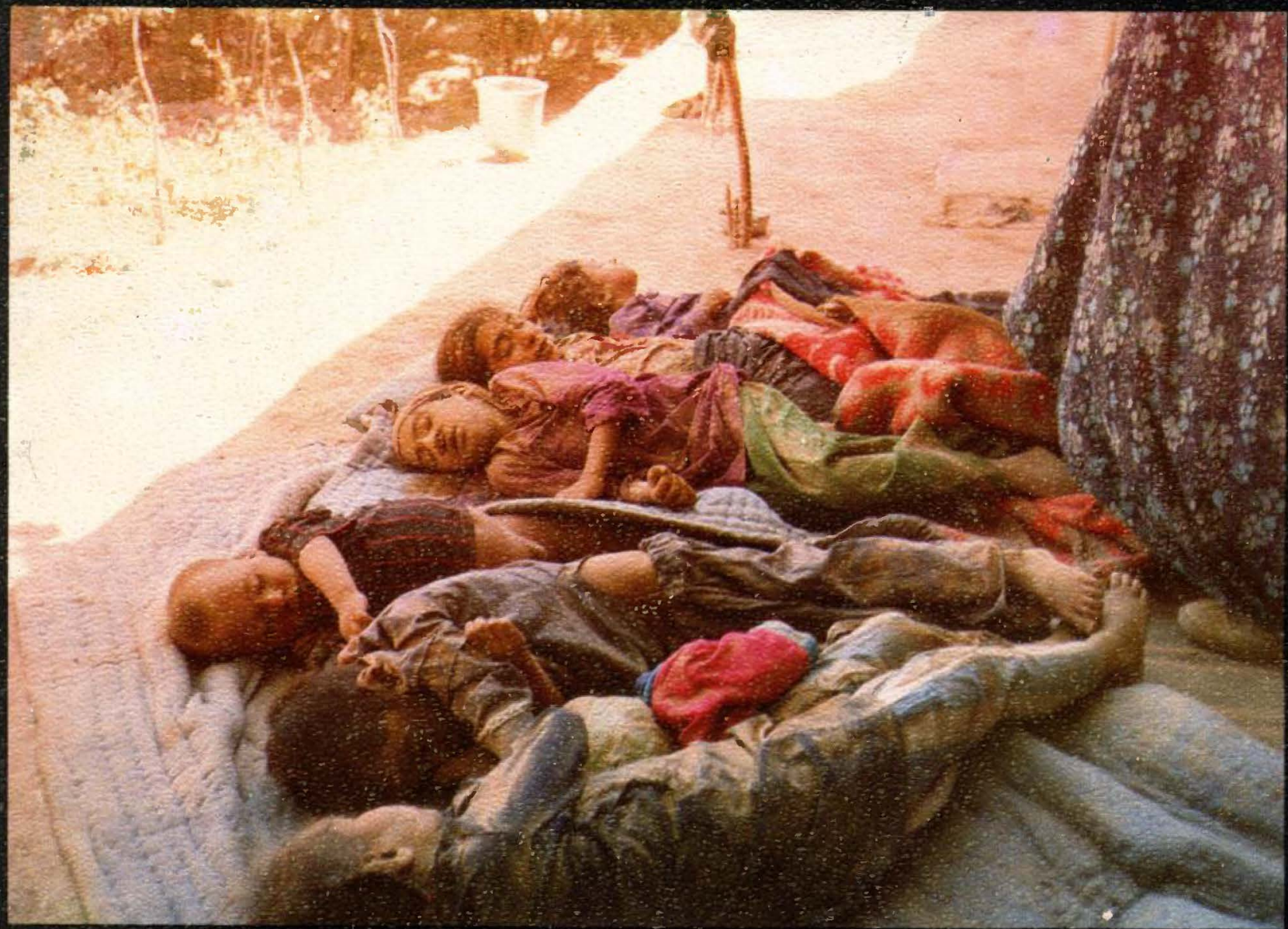




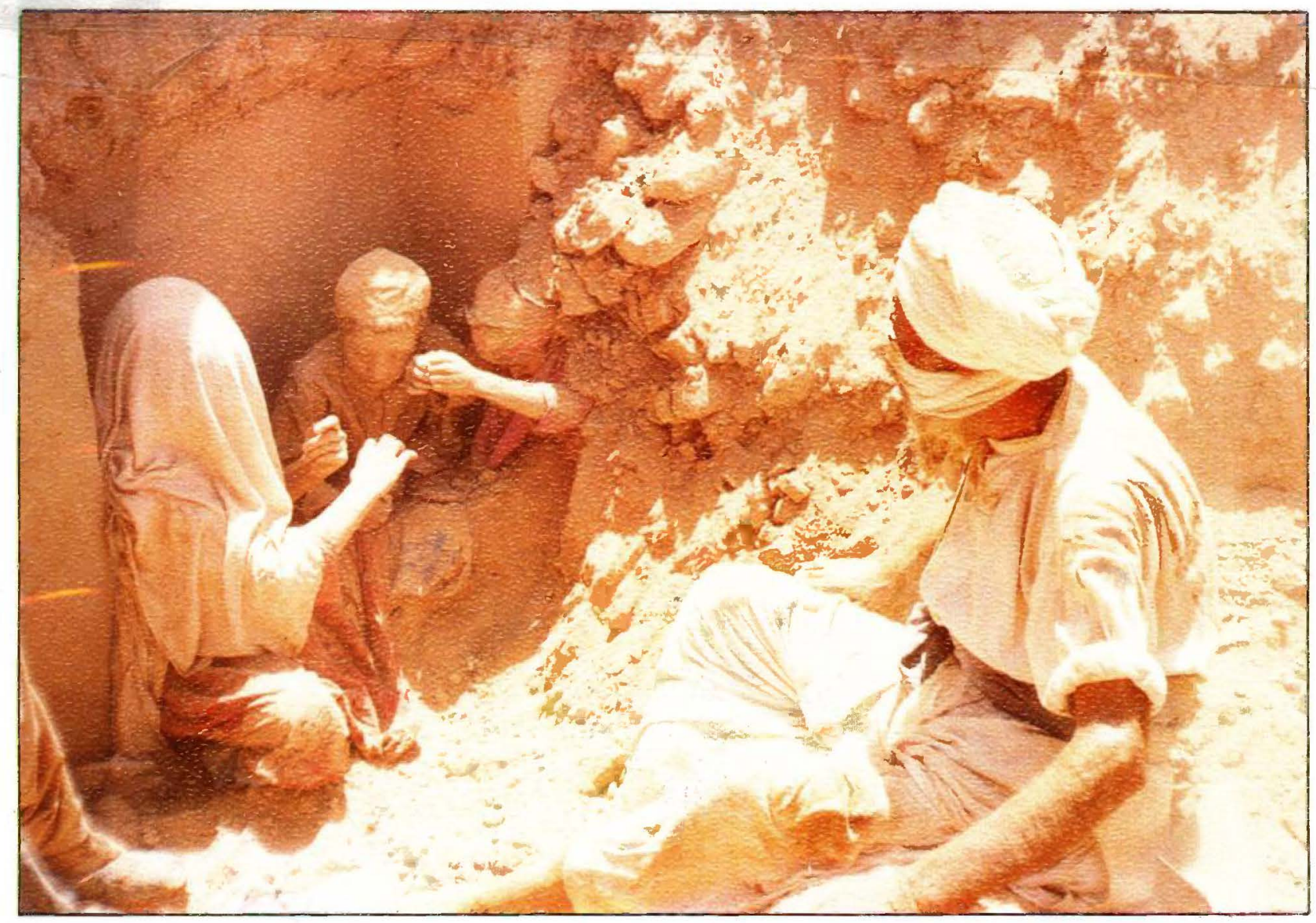

The half unearthed bodies of a mother and her two children when they were killed in a Russian bombing raid on Kushk Sirwan, Herat Province, on August $11,1987$. This is part of the so-called "reconciliation and peace" of the Russians. (CourtBy of AMRC)

\section{Cover Photograph}

The bodies of children unearthed from the rubble of Kushk Sirwan, Hirat Province, bombed by the Russians on August 11, 1987. 71 persons, mostly Women and children, were killed and 21 houses were destroyed in this attack. (Courthy of AMRC) 
Since about a year, the Russian Social Imperialists and their puppets in Afghanistan have launched a wide and intense propaganda campaign claiming that their so-called "national reconciliation" scheme has succeeded and that it will soon lead to a ceasefire and peace in Afghanistan.

In reality, however, the Russian Red Army and the puppet regime forces have not only escalated the fighting but in fact have increased in magnitude the barbarities and terrorization of the defenseless civilian population of Afghanistan. Though this pamphlet is too brief to give a comprehensive picture of what the Russian Imperialists and their puppet regime has done only in this one year of "national reconciliation", but it does provide a glimpse of the large-scale atrocities,massacres, and destruction committed by the so-called "defenders of peace and Justice" in Afghanistan.

In a Russian bombing raid, these children have lost their parents and their home. Now they have no place to live in and none to support them.

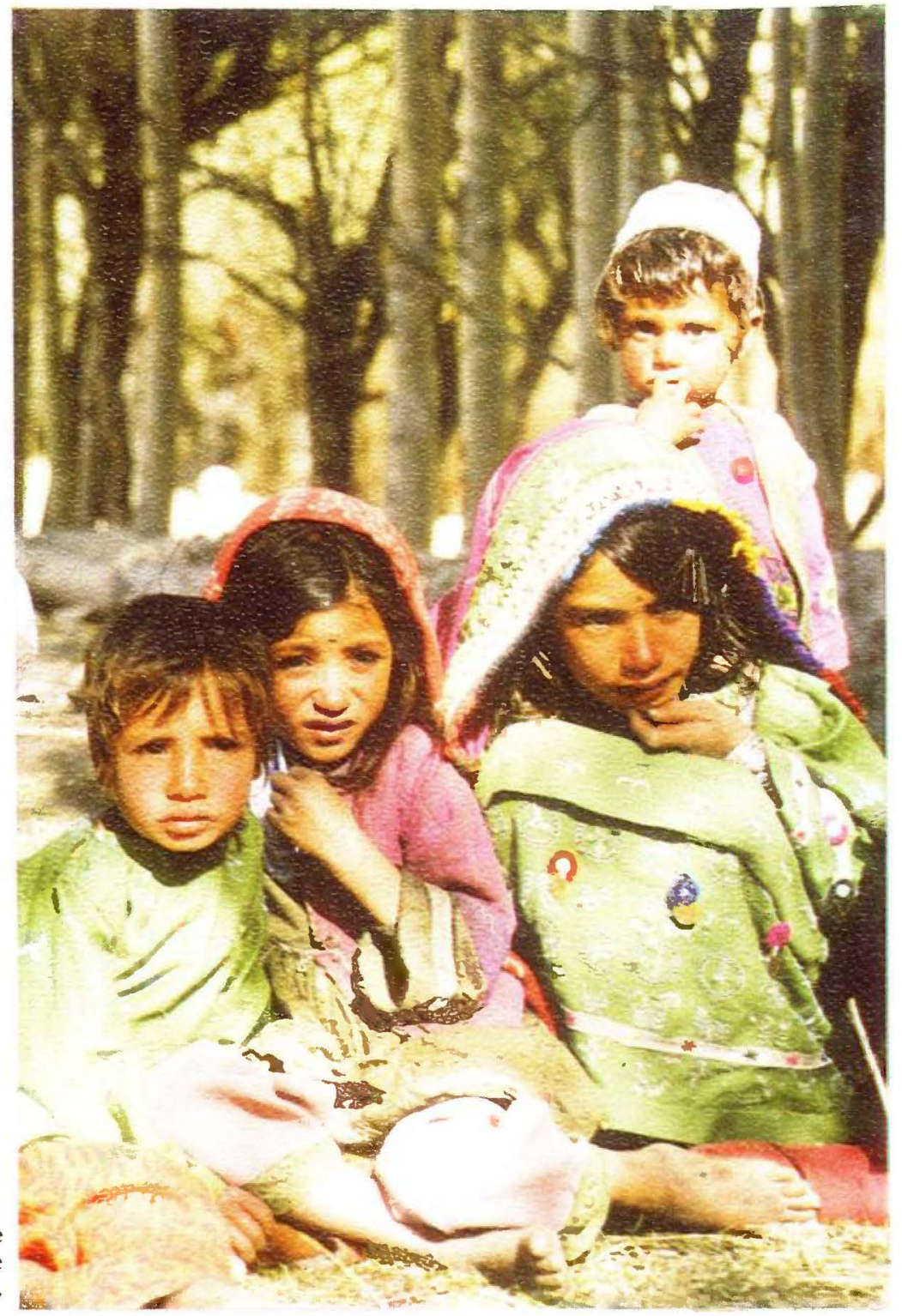




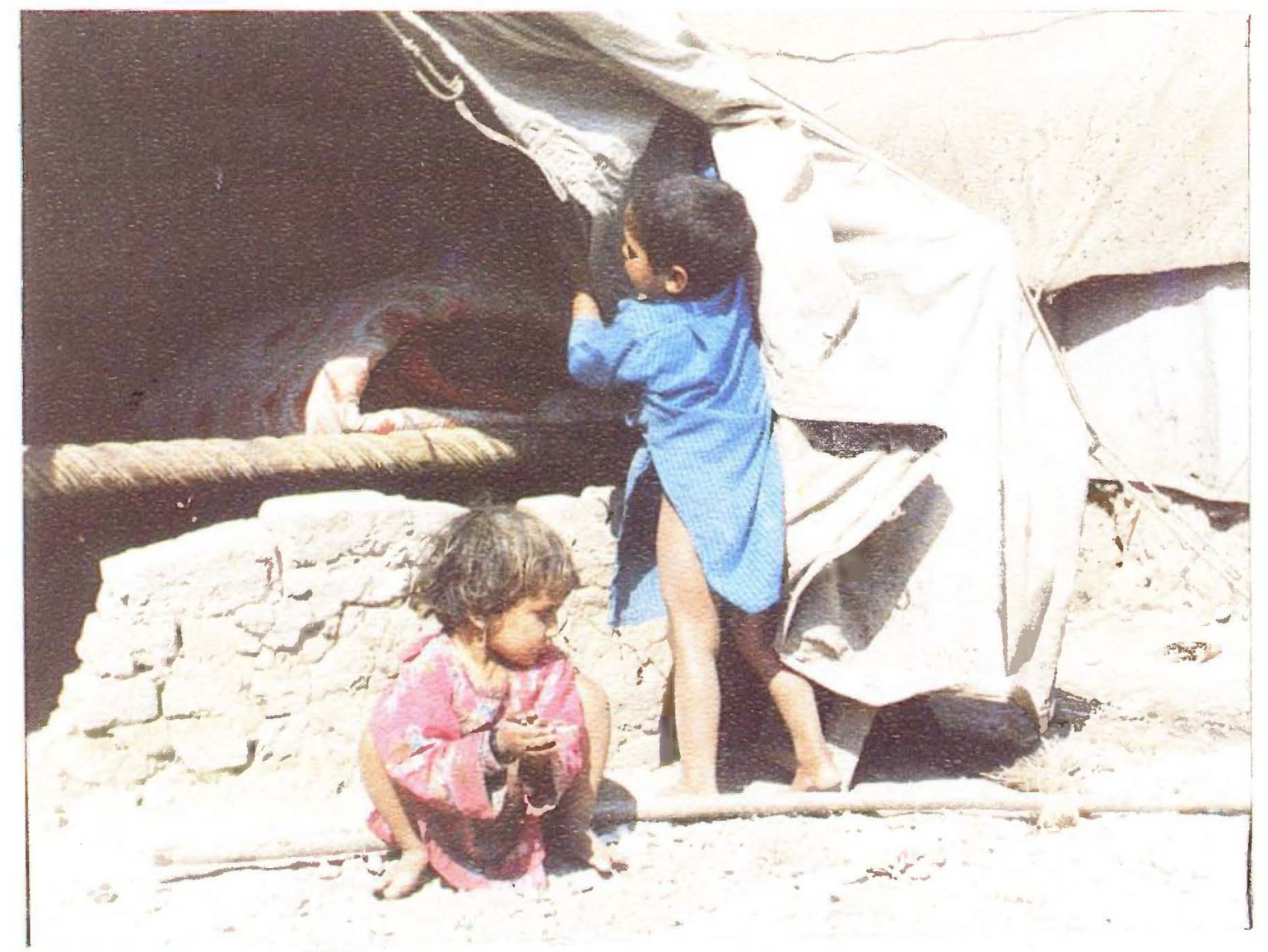

Hot deserts and scorching sun prevent these children from playing in the camps 
This young man was deprived of his leg as a result of Soviet anti-personnel mine.

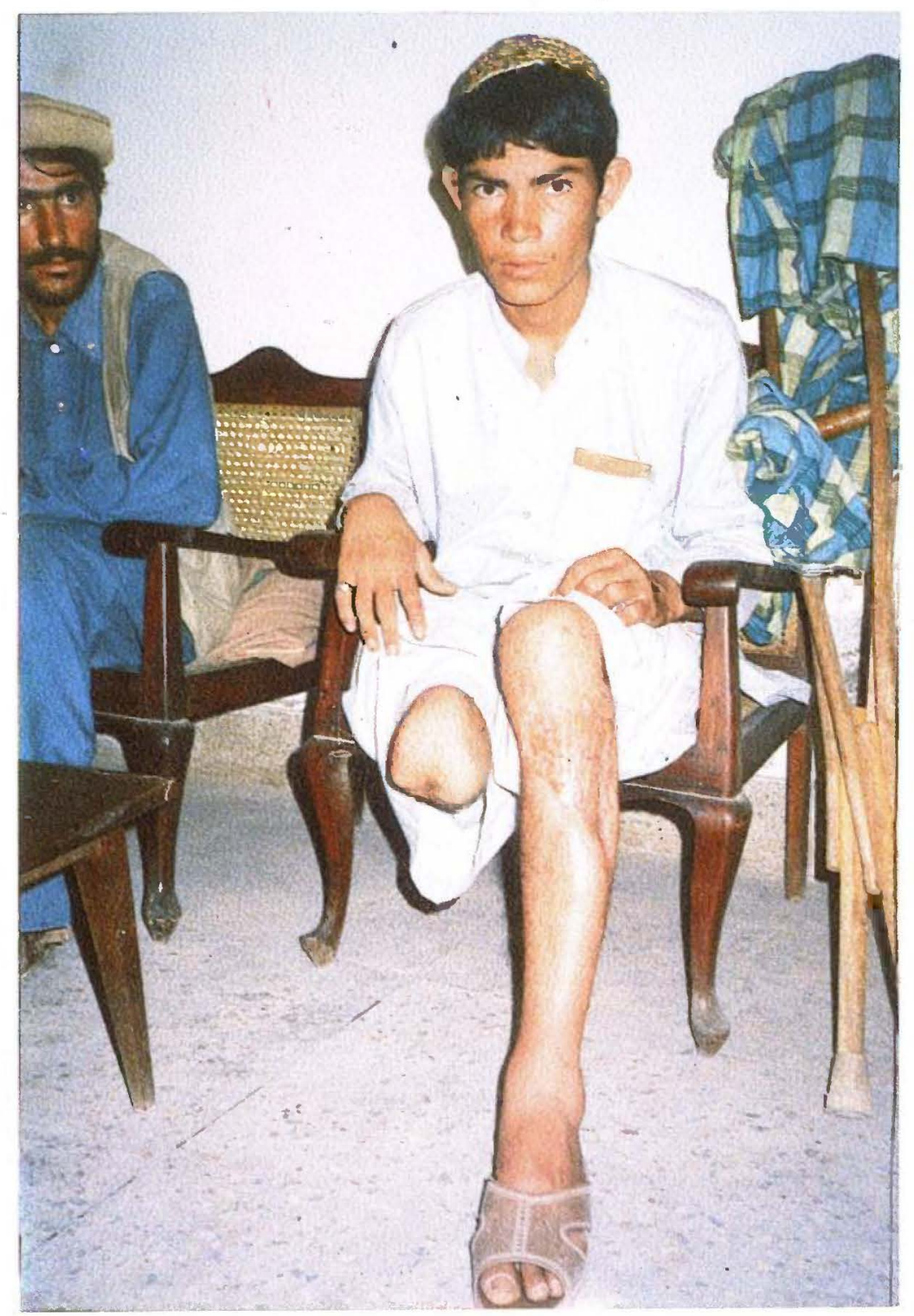




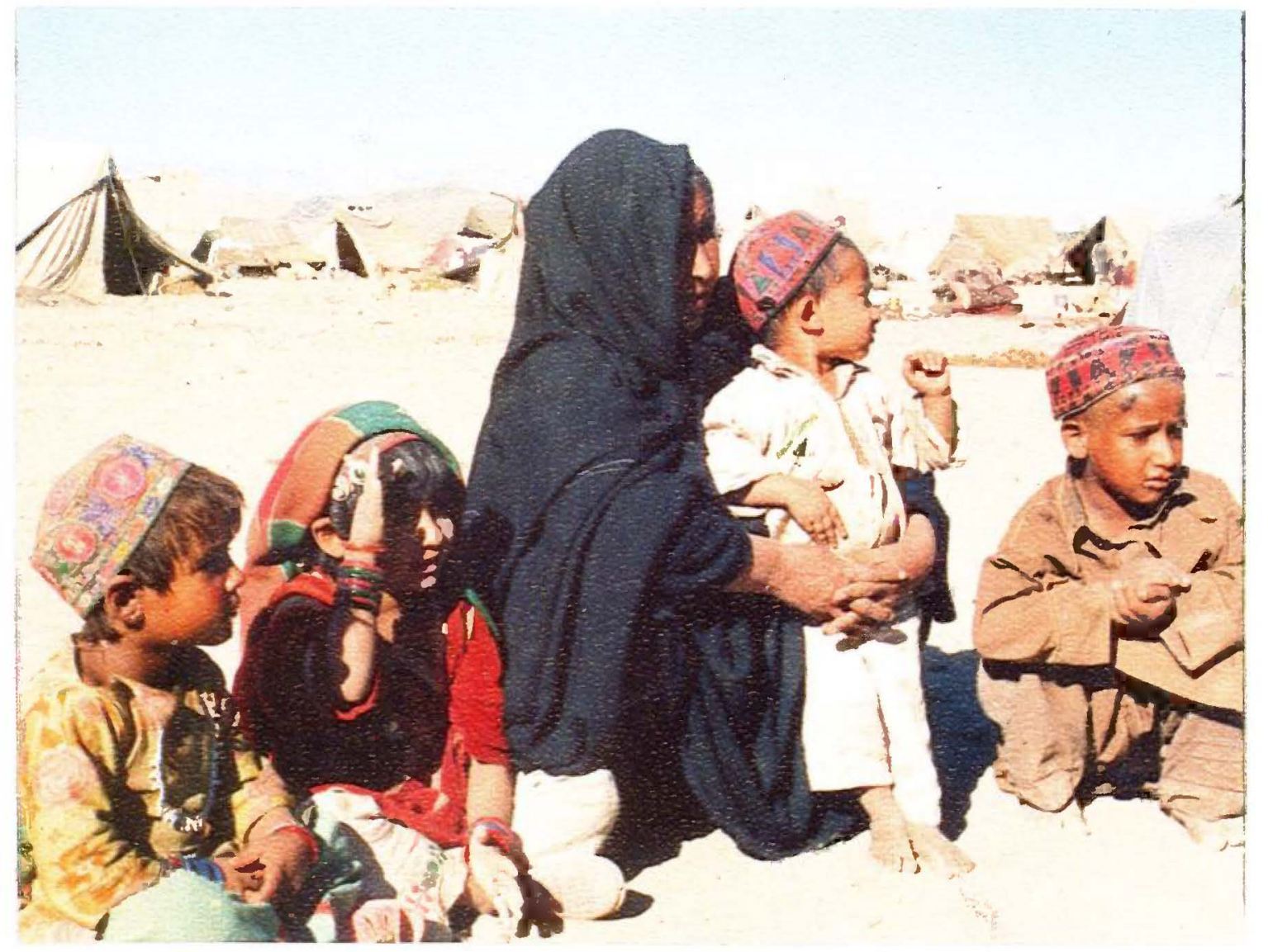

The Russians killed the bread-earner of this Afghan family, destroyed their house, and burned their crops. After joining other villagers, they travelled for many nights without food over very difficult mountaineous terraiss, avoiding daylight and Russian air-bombardments, to reach the safety of Pakistan. 
The Russians intend to turn the present and future society of Afghanistan in to a crippled one.

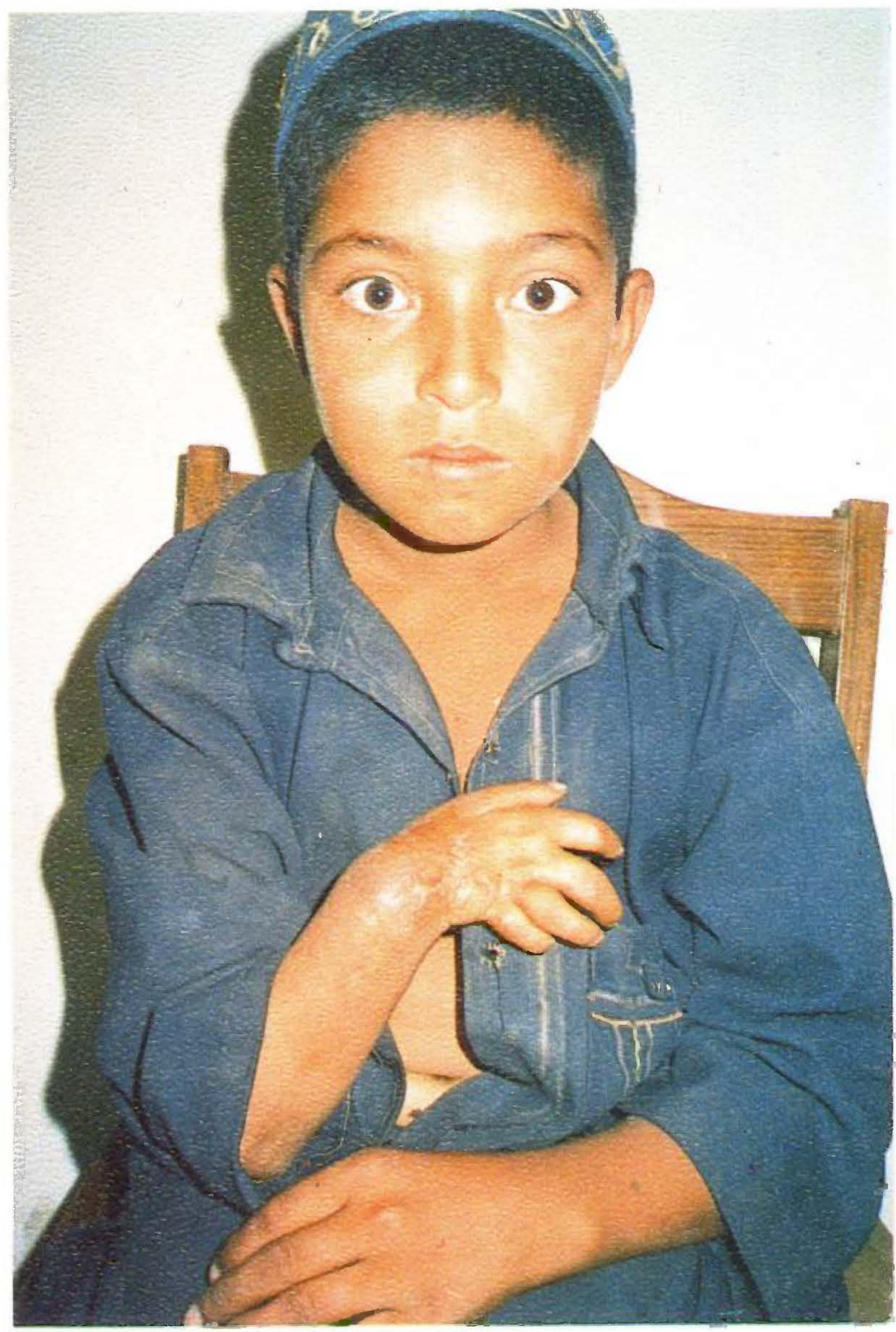




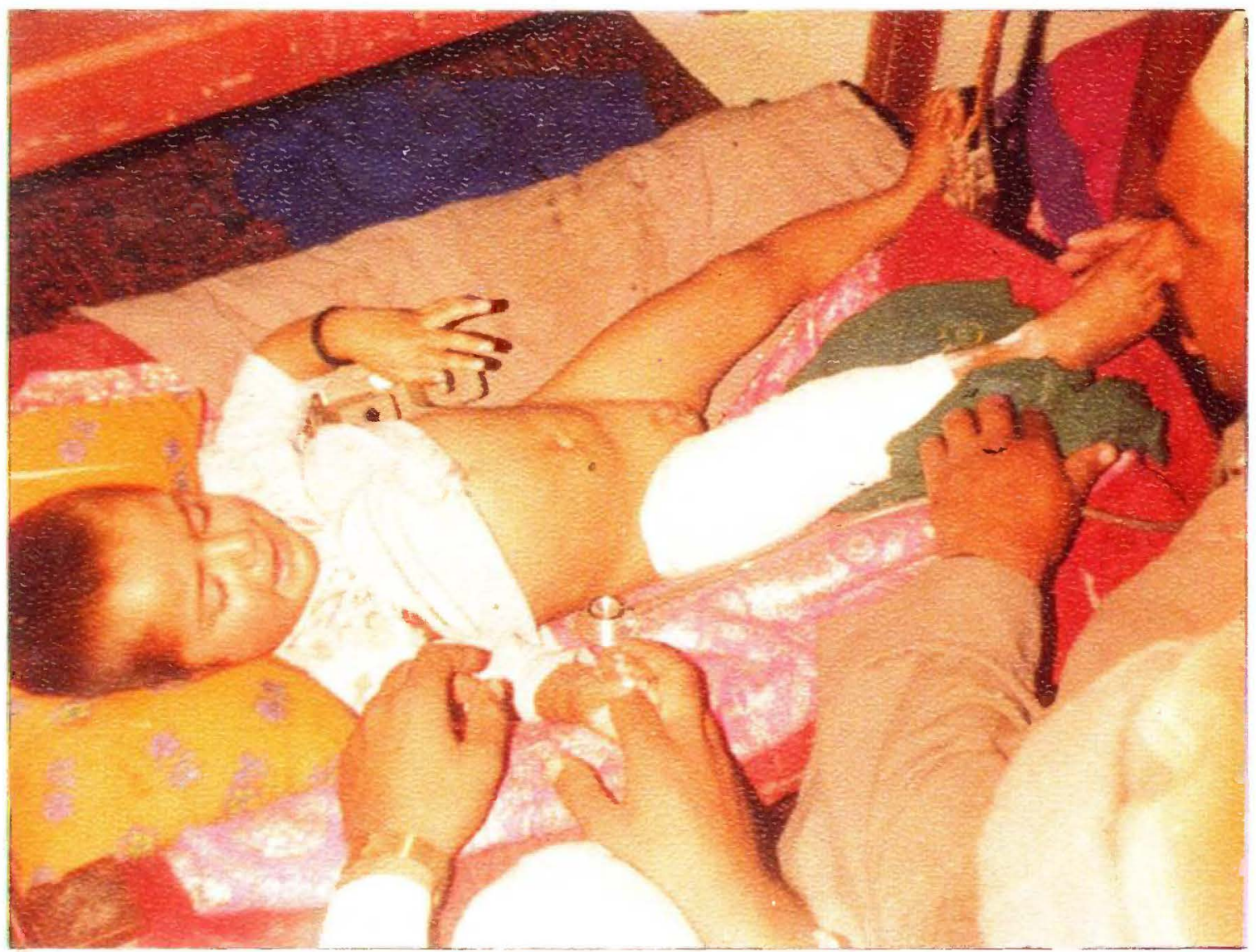

An Afghan refugee child hurt as a result of Russian bombardment on the Tribal Areas of Pakistan. 


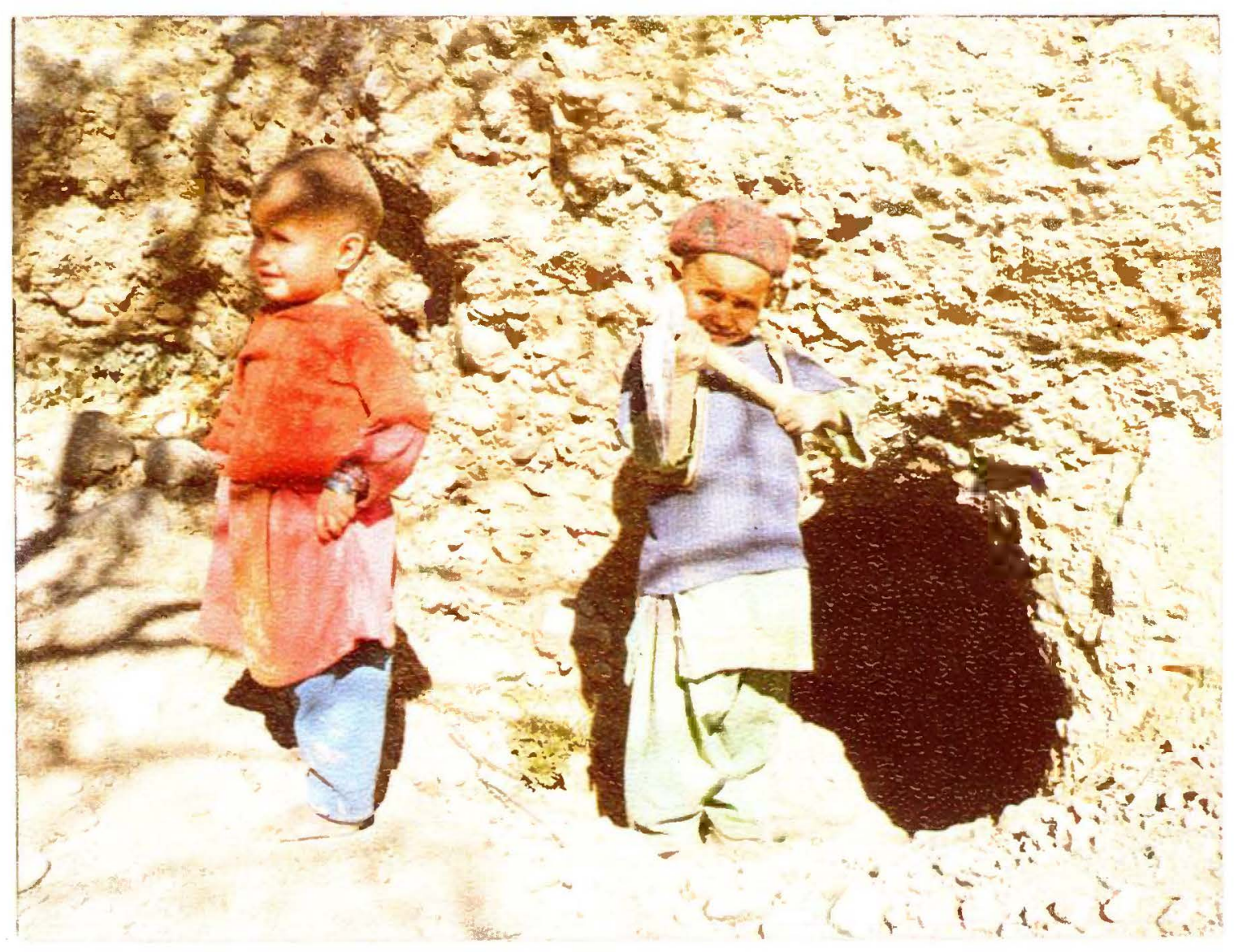

Against frequent Russian air-attacks, even these tiny hands have been forced to dig cave-shelters for themselves. 


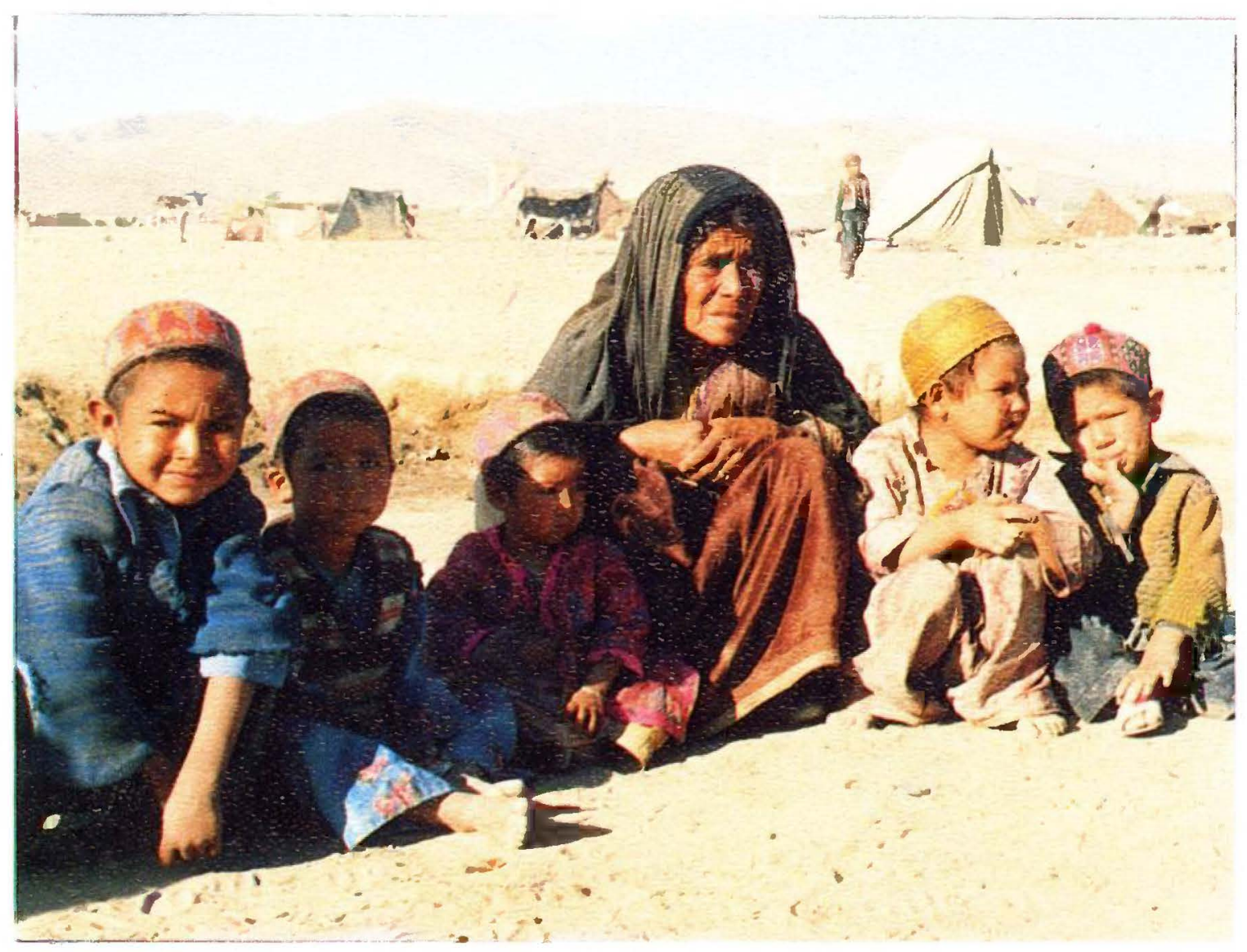

This Afghan refugee family near the Pak-Afghan border is waiting eagerly for humanitarian aid. 


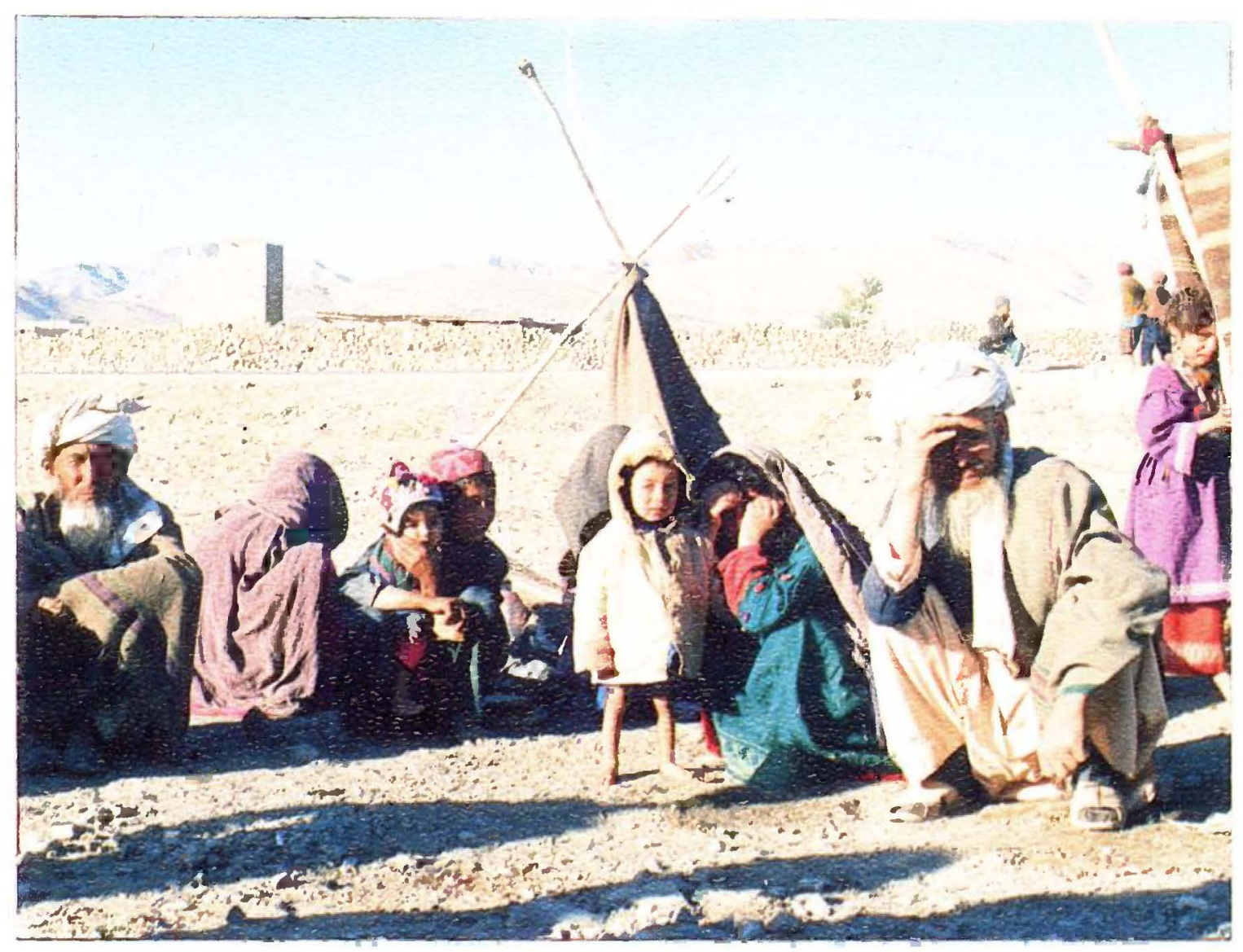

They were forced to seek refuge in Pakistan after their village was destroyed in Russian air-bombing. 


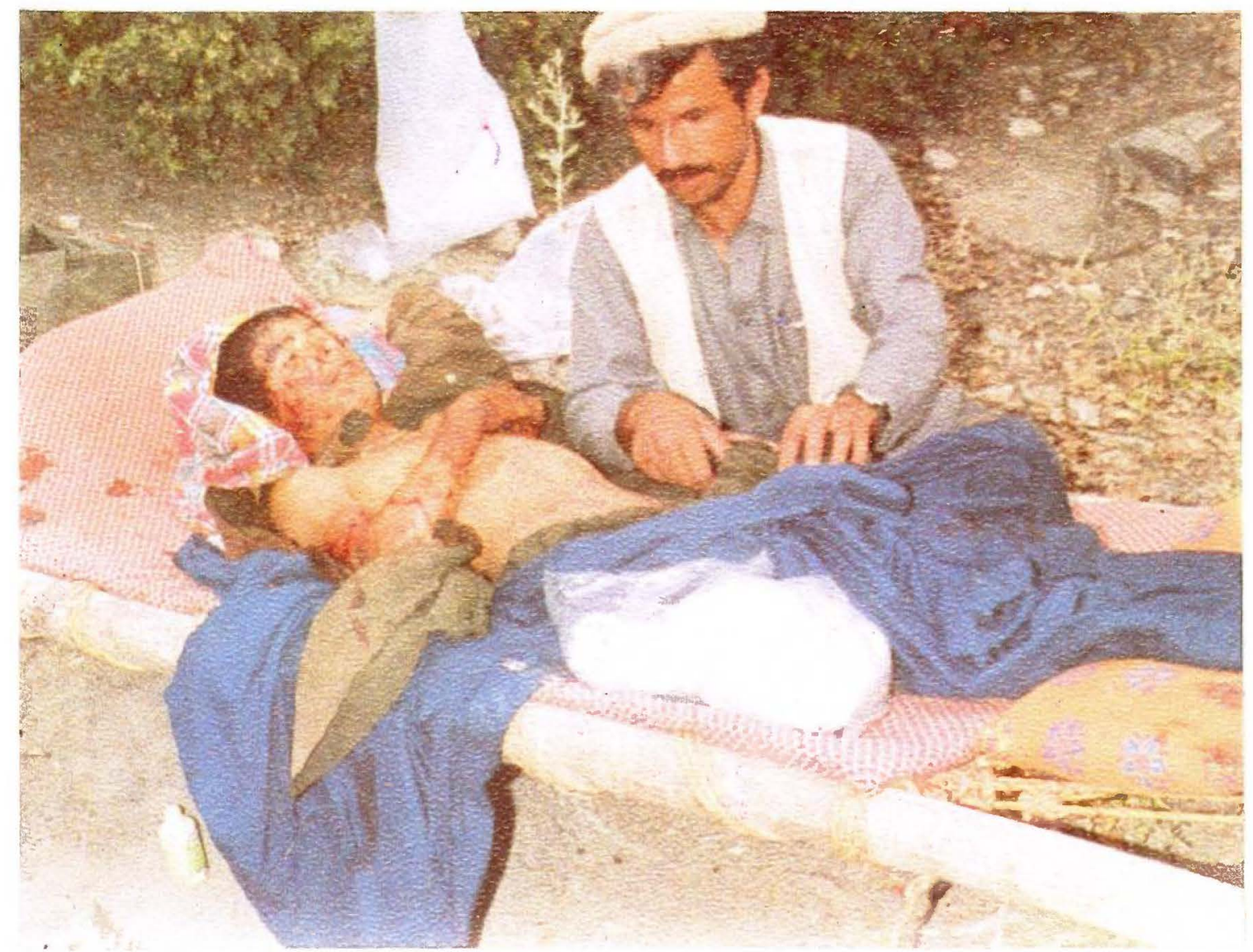

After his leg was blown by a mine, he was taken to a mujahideen clinic for treatment. But the mujahideen clinic too was bombed and he was again wounded. 


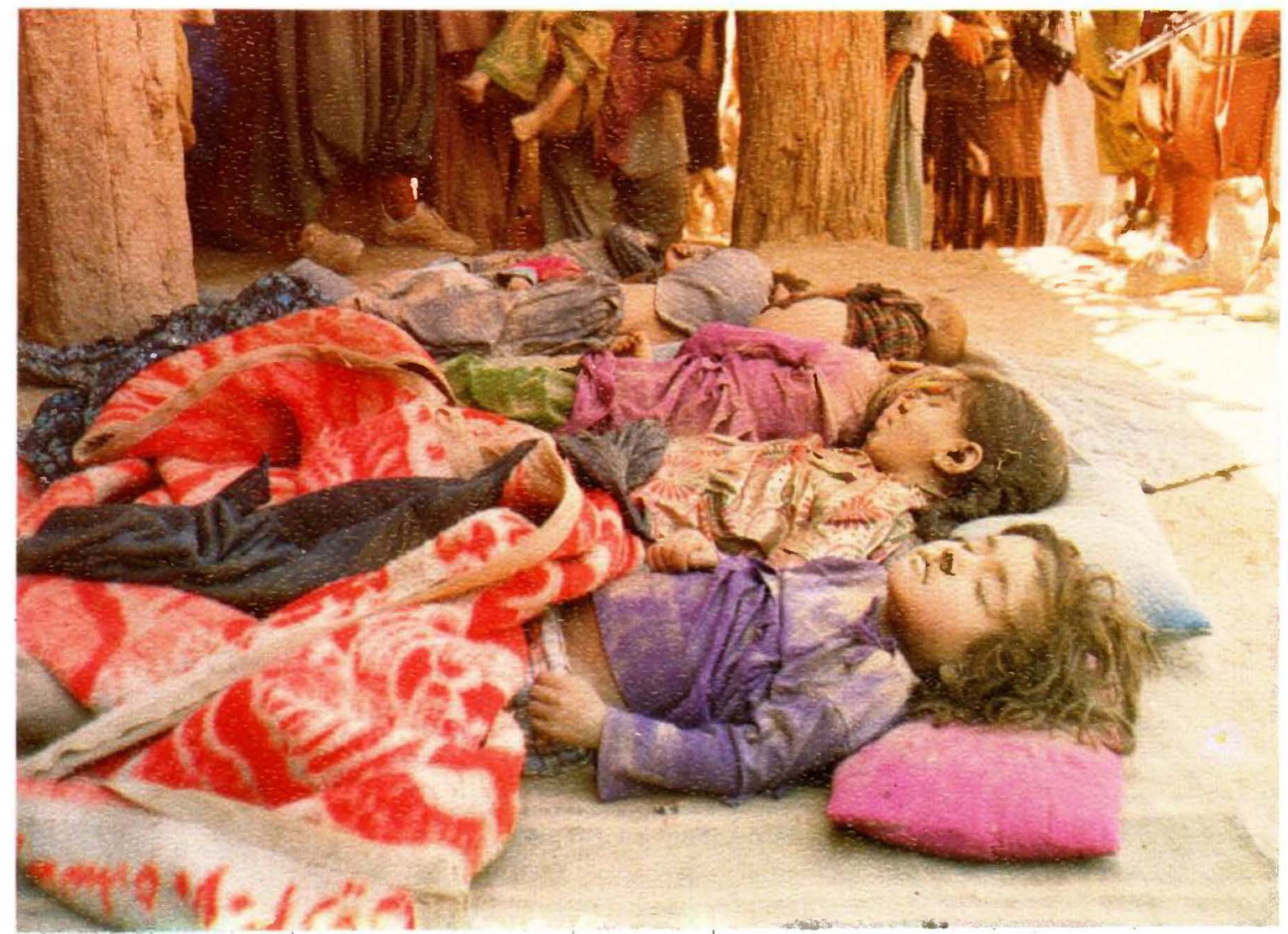

A group of children killed on 11 th of August this year in Hirat as a result of Russian air bombardment. (This is how the Russians express their love for children) (Courtsy of AMRC) 


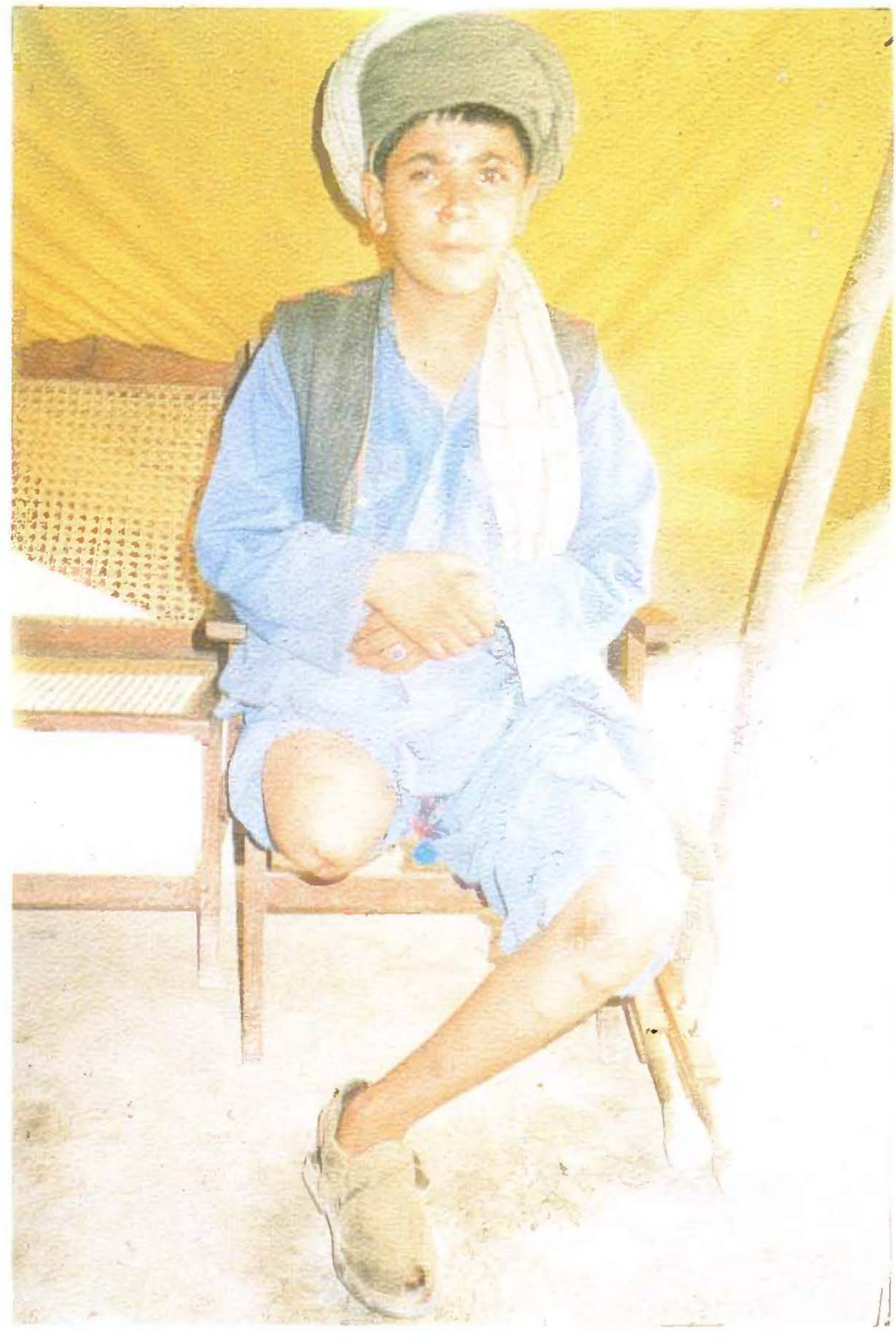

This is a picture of an 11-year old boy who lost his leg as a result of a Russian mine which exploded while he was on his way to his village. 


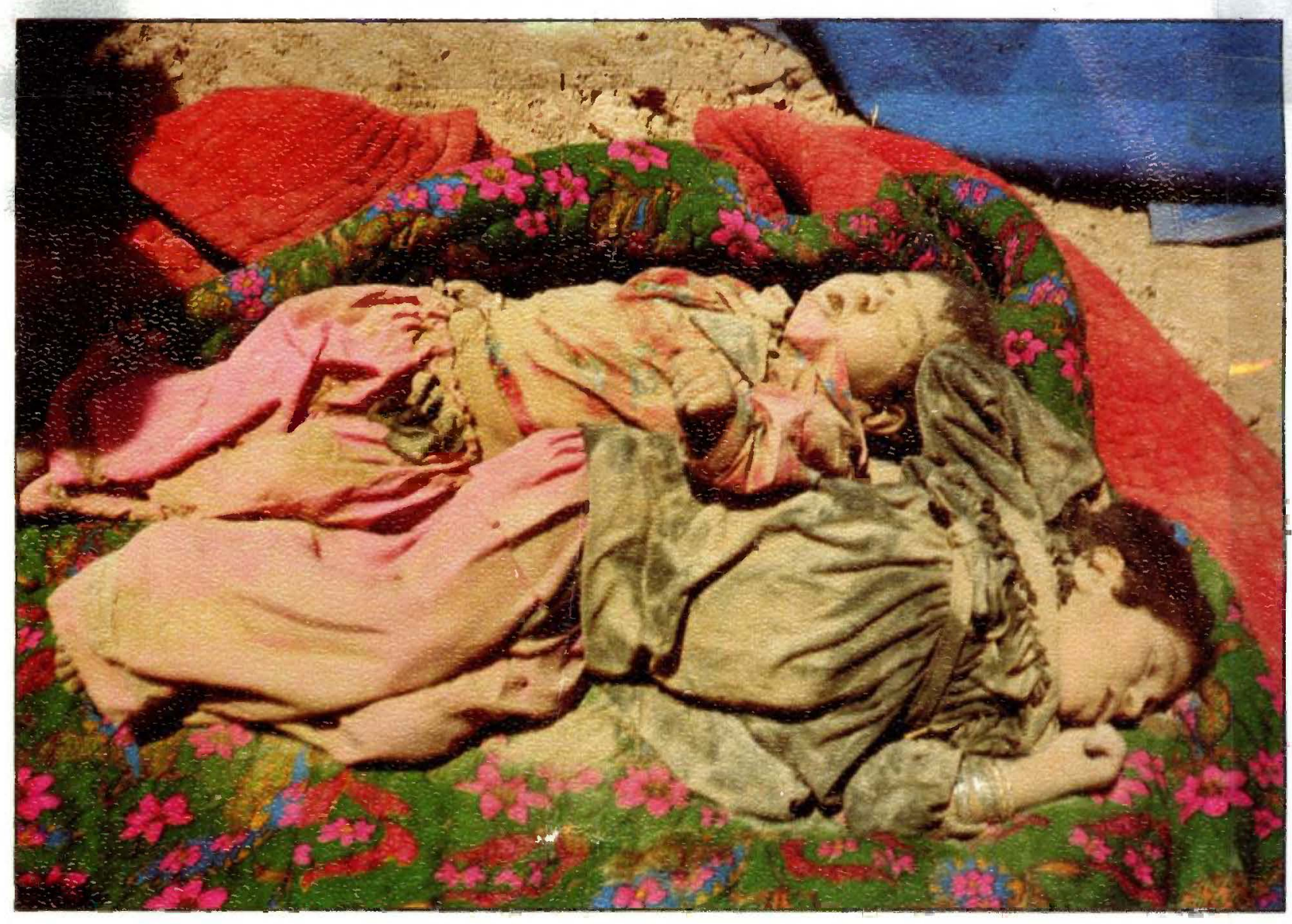

On 11 th of August this year four Russian jets attacked the Pakhtoon Zarghun Wolaswali killing a large number of children, women and old people.

This picture shows two children of the Allah Dad family being taken out of the rubble in which they were burried.(Courtey of AMRC)

\section{Published by}

Cultural Department National Islamic Front of Afghanistan 15

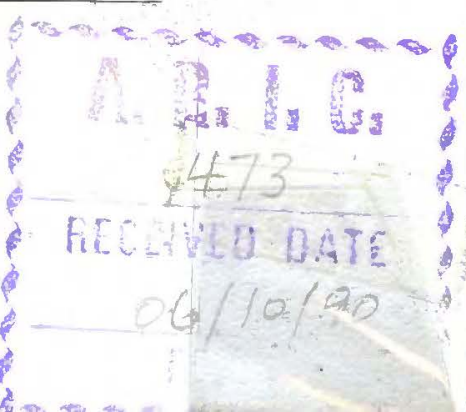



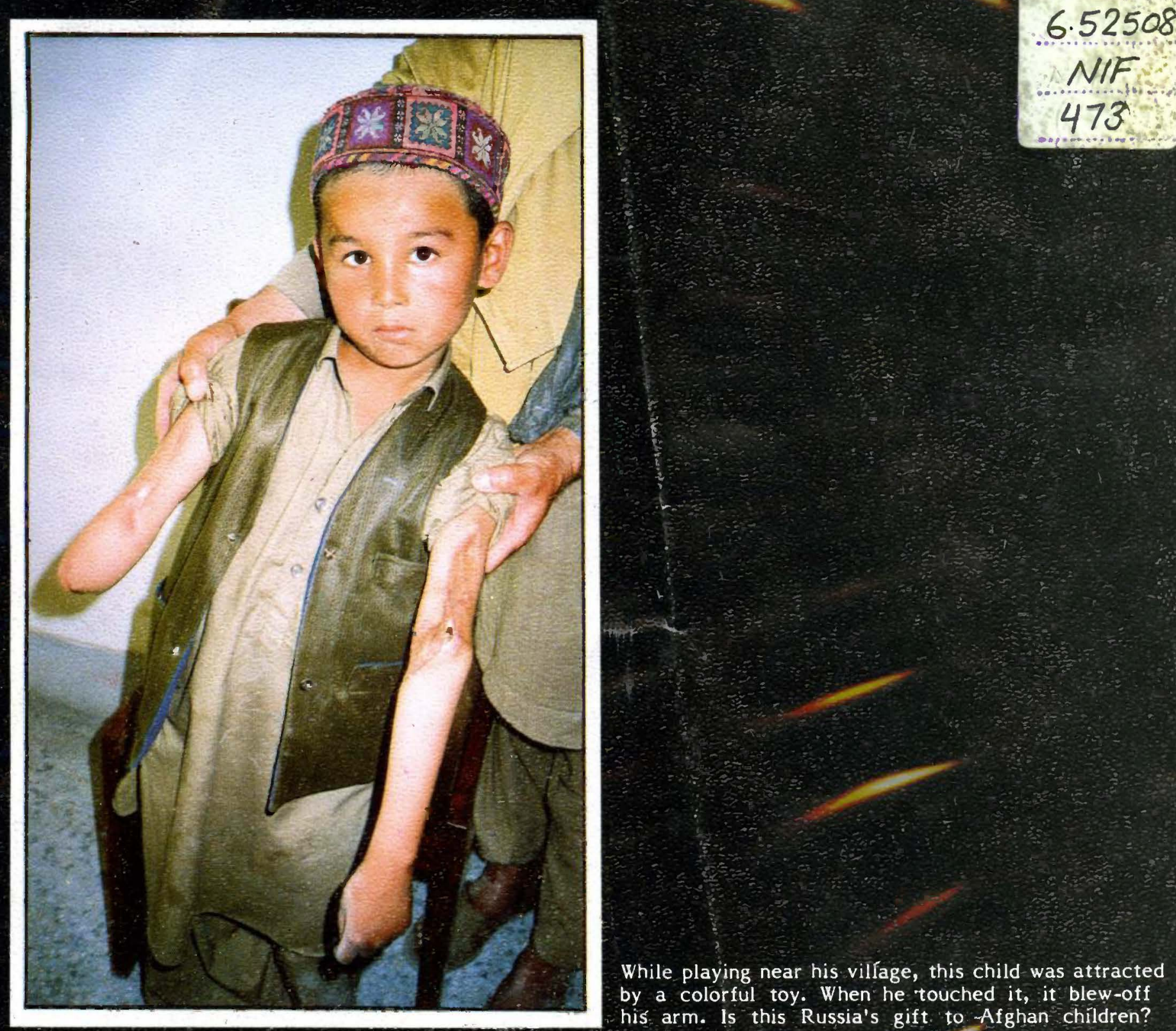

While playing near his village, this child was attracted by a colorful toy. When he touched it, it blew-off his arm. Is this Russia's gift to -Afghan children? 